This is an electronic reprint of the original article. This reprint may differ from the original in pagination and typographic detail.

Author(s): Kyppö, Anna

Title: Virtual Slovak : insight into learning Slovak in an e-learning environment

Year: $\quad 2015$

Version:

Please cite the original version:

Kyppö, A. (2015). Virtual Slovak : insight into learning Slovak in an e-learning environment. In J. Jalkanen, E. Jokinen, \& P. Taalas (Eds.), Voices of pedagogical development : expanding, enhancing and exploring higher education language learning (pp. 57-84). Research-publishing.net.

https://doi.org/10.14705/rpnet.2015.000287

All material supplied via JYX is protected by copyright and other intellectual property rights, and duplication or sale of all or part of any of the repository collections is not permitted, except that material may be duplicated by you for your research use or educational purposes in electronic or print form. You must obtain permission for any other use. Electronic or print copies may not be offered, whether for sale or otherwise to anyone who is not an authorised user. 


\section{Virtual Slovak: insight into learning Slovak tin an e-learning environment}

\section{Anna Kyppö ${ }^{1}$}

\section{Abstract}

$\mathrm{T}$ his paper offers insight into learning Slovak in an e-learning environment. The need to reach distance-learners of Slovak led to the implementation of a web-based course on Slovak language and culture in 2008-2010. The pedagogical basis of the course, called Virtual Slovak, is the socioconstructivist approach to teaching and learning, in which the focus is on the development of learners' communicative competence. This teaching experiment led to a study in which the focus was on learners' beliefs and experiences regarding learning Slovak in an e-learning environment. The results showed that this particular learning environment had a positive impact on the development of learners' agency. This impact was demonstrated by an evident increase in motivation and language learning awareness as well as in a conscious approach to learning. At the centre of this investigation is the evaluation of the e-learning environment, especially its appropriateness at the beginners' level for the acquisition of a less commonly taught language, as well as of the teacher's role in the learning process. Furthermore, the results revealed that learners' attitudes towards learning in technologyenhanced learning environments pose challenges to the instruction of less commonly taught languages. Even though current digital technology offers multiple opportunities for the integration of new media modes into learning activities, the choice of relevant media for the learning context and learners' competences seems to remain one of the teacher's main responsibilities.

\section{Keywords: e-learning, learning environment, Slovak, less commonly taught languages, LCTL, communicative competence.}

1. Language Centre, University of Jyväskylä, Finland; anna.kyppo@jyu.fi

How to cite this chapter: Kyppö, A. (2015). Virtual Slovak: insight into learning Slovak in an e-learning environment. In J. Jalkanen, E. Jokinen, \& P. Taalas (Eds), Voices of pedagogical development - Expanding, enhancing and exploring higher education language learning (pp. 57-84). Dublin: Research-publishing.net. doi:10.14705/rpnet.2015.000287 


\section{Context of the study}

This study offers insight into learning Slovak in an e-learning environment. One of the challenges for teaching in the last decade or so has been the design of new learning environments for language learning and the efficient employment of versatile $\mathrm{ICT}^{2}$-enhanced approaches and resources. The development of new course content and learner training modules, as well as of collaborative practices between teachers and students within distance learning programmes focusing on the efficiency and multimodality of learning materials, generated the idea of a new learning environment designed specifically for learning Slovak. The Slovak e-learning course Virtual Slovak was designed and piloted in 2008-2010. The pedagogical basis of the course is the socioconstructivist approach to teaching and learning. The main focus is on the development of learners' communicative competence, which is perceived as their linguistic and pragmatic knowledge about a language and their ability to create meaning in the target language. This teaching experiment then led to an investigation of how Slovak is acquired in an e-learning environment. The main focus is on the learners: how they experience their learning in such an environment and what they believe they have or have not learned.

\subsection{Slovak}

Slovak is an Indo-European language belonging to the group of West Slavic languages, together with Czech, Polish and Lower and Upper Sorbian. In addition to the roughly 4.5 million Slovaks living in Slovakia, Slovak is also spoken in other parts of the world, with altogether about 2.7 million speakers of Slovak outside of Slovakia (Ondrejovič 2009). Slovak is the official language spoken in the Slovak Republic. Due to its regular structure and closeness to all Slavic languages, it is often called the lingua franca of Slavic languages. Together with approximately 30 other languages, Slovak is one of the Less Commonly Taught Languages (LCTL) (Brecht \& Walton 1994).

2. Information and Communications Technology 


\subsection{Slovak in Finland}

Studies of Slovak language and culture are offered by more than 40 universities around the world. In the Nordic countries, however, the only academic institution of higher education that has offered Slovak studies for over 30 years is the University of Jyväskylä. In addition to various projects aimed at the translation of Slovak literature into Finnish and the dissemination of knowledge about Slovakia in Finland, one of the greatest challenges was the design of an open, web-based learning course of Slovak. To meet this challenge, Slovak instruction had to move through several stages of development aimed, first, at the enhancement of self-directed learning, and second, at the integration of ICT into language teaching. In the early 2000 s, the instruction of Slovak became more multimodal due to the integration of educational and communication technology into so-called traditional instruction (Kyppö 2007). The next challenge was the design of efficient learning materials for distance learning, and finally, the implementation of the e-learning course, which was piloted with two groups of students in 2008-2010.

\section{Slovak e-learning course: pedagogical principles}

This section introduces the main concepts and theories supporting the development and implementation of the Slovak e-learning course. These concepts include the socioconstructivist approach to learning; ComputerAssisted Language Learning (CALL), frequently referred to as e-learning; communicative competence, which I consider to be one of the most important objectives of any process of language learning; and learners' agency manifested by an increase in their motivation and language learning awareness as well as the growth of deep and strategic approaches to learning.

\subsection{The socioconstructivist approach to learning}

In constructivist learning theories, learning is perceived as an active process in which knowledge is constructed on the basis of learner's personal experiences. 
Social constructivism emphasises the importance of the cultural and social context (learning environment) and learner-centeredness. The term learning environment evokes an image of a place and a space, that is, "room to move and explore" (Wilson 1996: 4). Thus the learning environment may be determined by various physical and virtual locations. In the context of the current study, the learning environment is the overall context of learning which involves not only the e-learning platform and course setting, but also students' attitudes to learning, their histories and their learning cultures.

The focus of the approach is on student activities and the development of their communicative competence. Problem-based instruction and peer collaboration among the learners as well as between the learners and the teacher are in the foreground. As constructivism allows for flexibility, imagination and creativity, constructivist learning environments are generally designed so that they promote the autonomy, creativity and engagement of the students and the teacher. One of the variations to the constructivist-cognitive learning theories, which emphasise the learner's key role in the learning process, is Johnson's (2004) model of Second Language Acquisition (SLA). This model is based on the dialogical framework of Vygotsky's (1986) sociocultural theory and Bakhtin's (1981) dialogised heteroglossia. In SLA, the focus is on learner's problem-solving cognitive skills and the skills of linking the acquired knowledge and skills to those which have been previously acquired. Second language acquisition is viewed in terms of performance. Learning a new language does not occur in the human brain, but in the interactions conducted in sociocultural settings. Bakhtinian dialogism, which also emphasises the interactional and dynamic aspect of language, has been used to frame language learning as a continuous dialogue between language and the external world, between the language learner and his/her inner world, between the language learners themselves, and between the learners and the teacher (Dufva 1994b). As the constructivist theories of learning emphasise the importance of learningby-doing, learning tasks - their nature, structure and performance - are central. In accordance with Task-Based Learning (TBL) (Willis 1996), the objective is not only to enhance the learner's current language skills, but also the teacher's imagination and creativity. The teacher is responsible for providing learners 
with the whole range of tasks which may motivate them to experiment with the language and use it spontaneously, as in so-called real life - hence the origin of second language competence, which, as suggested by Johnson (2004), lies in the interaction between language competence (knowledge of the language) and performance (the skills of using the language in real or almost-real life contexts).

\subsection{E-learning: asynchronous, synchronous and blended learning}

E-learning has become popular due to its flexibility in terms of time and space as well as for its learner-centeredness. It is generally characterised as less expensive to support and not constrained by geography, and thus it is appropriate in almost all contexts. It may be implemented either asynchronously or synchronously.

Asynchronous e-learning (e.g. emails, discussion boards) is considered to be a key component of efficient e-learning due to its flexibility (freedom from time and space) and thus essential for collaboration. Learners may enter the e-learning environment at any time and then spend longer periods on various learning activities. According to Robert and Dennis (2005), asynchronous communication increases learners' ability to process information and supports their cognitive participation.

On the other hand, synchronous learning (e.g. chat, videoconferencing, faceto-face learning) may be perceived as a more social activity in which learners are participants rather than isolated learners, a status which often results in an increase of commitment and motivation (Kock 2005). Synchronous e-learning primarily supports learners' personal participation.

Furthermore, combining face-to-face classroom instruction and computermediated activities, with the aim to form an integrated instructional approach, offers an opportunity to redesign teaching (Vaughan 2010). In blended learning, both modes of e-learning, the asynchronous (e.g. a course management 
system, e-learning environment) and synchronous learning (virtual classroom) accompanied by face-to-face sessions, may be used. If designed and used meaningfully, the result may be an evident increase in learners' self-directed learning and clear development of communicative competence.

Mayes and de Freitas (2013) proposed a curriculum design model for e-learning that includes the descriptions of the intended learning outcomes, the design of teaching and learning activities, the assessment of achieved outcomes and assessment of the curriculum alignment. Their curriculum design is based on constructive alignment, in which all teaching elements, expected learning outcomes, teaching methods, tasks and assessment procedures are aligned with each other and turned into learning activities (Biggs 2003). As the focus of the constructivist pedagogical approach is always on doing, learning and teaching activities are placed at the centre of the process. One of the implications of this model for teaching is how it reshapes the sociocultural setting of a learning environment into one that is more favourable and motivating. In practice, it means the design of a genuine social context. The interaction in such a context, like in this course, may take various forms, including collaborative or knowledge building dialogues with peers or online resources, or various real-life simulations.

\subsection{Communicative competence}

Because one of the key questions of this study is learning Slovak in an e-learning environment, a key assumption is that learning, which is expected to result in the acquisition of the four language skills (reading, listening, writing and speaking), is reflected in the level of communicative competence. Communicative competence can be viewed from various perspectives. The Common European Framework of Reference for Languages (CEFR 2001: 9) defines communicative competence as "the sum of knowledge, skills and characteristics that allow a person to perform actions". In the light of this definition, learners' communicative competence includes three types of competence: sociolinguistic, pragmatic (discourse and functional) and linguistic (lexical, grammatical, semantic, phonological, orthographic and orthoepic). 
As Johnson (2004) has claimed, the origin of second language competence lies in the language use that takes place in real social contexts. In practice, learners are expected to learn not only the language, but also what to do with the language, that is, how to use it in real-life contexts. To that end, they need to develop their knowledge of the target culture and its practices, and through that enhance their intercultural awareness (Byram, Nichols \& Stevens 2001).

\subsection{Learner agency, motivation, awareness and approaches to learning}

The focus of this section is on learner agency. A number of authors have identified agency as being demonstrated by an increase in learners' motivation, language learning awareness and development of deep or strategic approaches to learning (see Basharina 2009; Entwistle 2001; Kyppö 2014).

\subsubsection{Learner agency}

Agency and motivation are often intertwined. Both of them are closely related to self-determination, autonomy, responsibility, locus of control and selfefficacy (Brown 2014). Agency may be perceived as one of the key concepts in learning, as a movement, a change of state or direction, or even as "the lack of movement where movement is expected" (van Lier 2010: 4). Drawing on van Lier (2010), agency in the context of this study is perceived through the increase in learners' motivation and in their consciousness of the target language and learning (language learning awareness). Furthermore, agency is reflected in their approaches to learning. Van Lier (2010) sees that the employment of agency significantly depends on the learning environment, including the whole context of learning and an agency-promoting curriculum.

\subsubsection{Motivation}

One of the most evident manifestations of learner agency is motivation. The main force for engaging in goal-oriented learning (mastery or performance orientation) is constituted by motives (Engeström 1999). They not only affect the outcomes 
of learning but also determine the conditions under which the learning goals are implemented and directly or indirectly affect the circumstances of learning (learning context) both spatially and temporally (Johnson 2004). Dörnyei (1998: 117) claims that motivation provides "the primary impetus to initiate learning the L2 and later the driving force to sustain the long and often tedious learning process". His model of L2 motivation (Dörnyei 1991) is composed of a set of motivational components that includes, among others, learner's motivational strategies and group cohesiveness. Motivational components involve the level of language, the learner, and learning situations related to various aspects of language learning such as curricula, teaching materials and methods, and learning tasks. However, one important factor that substantially affects the degree of learner motivation is the teacher's enthusiasm and commitment (Dörnyei 1998; Dufva 1994a).

From the viewpoint of technology-enhanced language learning, an interesting issue is the impact of new language learning environments on learner motivation. Ushida (2005), among others, has explored the role of learner attitudes and motivation in L2 learning within an online language course context. Her study provides evidence for the relation between the learners' motivation and the development of their language proficiency. The learners with positive motivation and attitudes managed to control their study in both face-to-face and independent learning sessions. Their results, in other words, corresponded to their effort. Interestingly, the teacher-specific motivational components were considered to be crucial in student evaluations of learning situations in the online courses. This study also points to the relation between learners' motivation and the development of their language proficiency. However, maintaining motivation throughout the course appeared to be one of the teacher's greatest challenges.

\subsubsection{Language learning awareness}

In this study, awareness means the consciousness of the target language, of its specific features and relations to other languages as well as consciousness of learning the language. This concept includes the knowledge of the culture represented by the target language, what Dufva (1994a) identifies as cultural 
awareness. In Dufva's (1994a) view, language, interaction and culture are intertwined aspects of language awareness. Language awareness may also be seen as the same as learners' ability to reflect on the learned language, on themselves as learners, and to recognise the similarities and differences between languages. But there are questions of what the learners become aware of and what has an impact on their learning awareness. The answer may be motivation, hence the close relatedness of these concepts. However, most significant is the impact of learners' everyday knowledge, that is, their personal experiences. These may be related to the target language, to their views of the language itself or to learning a language, as well as to so-called common knowledge, the sociocultural views of the target language and culture.

Bilash and Tulasiewicz (1995: 49) perceive language awareness as a key concept in the learner-centred classroom. In their opinion, language awareness is the integration of four elements: "content about language, language skills, attitudinal education and metacognitive opportunities, which allow the student to reflect on the process of language acquisition, learning and language use" (Bilash \& Tulasiewicz 1995: 49).

Ellis (2003) believes that one of the most important awareness-raisers is the teacher. The teacher is responsible not only for the design of the curriculum and tasks, but also for raising the learners' language awareness (consciousness) aimed at becoming sensitive to foreign languages. In the context of this course, language awareness was raised implicitly by the teacher, but also explicitly, as learners themselves discovered similarities and differences between their native languages and Slovak, built on their previous linguistic knowledge and developed their own language awareness.

\subsubsection{Approaches to learning}

Learning Slovak was explored in this study from the learners' viewpoint; from how the learners themselves experience their learning. The framework used to investigate their experiences is based on Entwistle's (2001) model of approaches to learning. According to this model, agency may be manifested through the 
use of deep, surface or strategic approaches to learning. The deep approach to learning refers to learners' active engagement with the content, which in turn leads to personal understanding of learning material. The surface approach indicates the reproduction, even the memorisation, of the learned matter. These concepts point to the strong impact of intentions and motivation related to learning. The third approach, strategic, is strongly based on the need for achievement (success or getting the best grades). This approach is characterised by the fear of failure.

To explore the role of agency in learning in international online learning environments, Entwistle's (2001) model was adapted by Basharina (2009). She found that students with a deep approach to learning use more effective learning strategies, seek meaning and therefore benefit the most from learning. Students with the strategic approach put consistent effort into learning. They provide themselves with the most favourable conditions for study, find good learning materials and monitor the effectiveness of their learning strategies (Basharina 2009; Thorpe 2002). Due to their good organisational skills, they generally cope well with time pressures and achieve good grades. On the other hand, the students with the surface approach usually have difficulties in making sense of the new ideas presented in a course and typically do not reflect on their purpose of learning, because their intention is mainly to cope with the syllabus requirements. They perceive the course as unrelated bits of knowledge and see little value in learning activities. In addition, they often suffer from the stress caused by the lack of time and planning. Basharina's (2009) model of approaches to learning presents learning as the result of a complex interrelationship between the affordances and constraints of a learning environment (physical or virtual) and the learner's agency.

\section{Course design: mountain climbing as metaphor for learning new languages}

This section introduces the Slovak e-learning course: its structure, layout and content as well as its ideology, which is based on the metaphor of learning as climbing (Figure 1 and Figure 2). 
Figure 1. Layout of the Slovak e-learning course (Kyppö 2014)

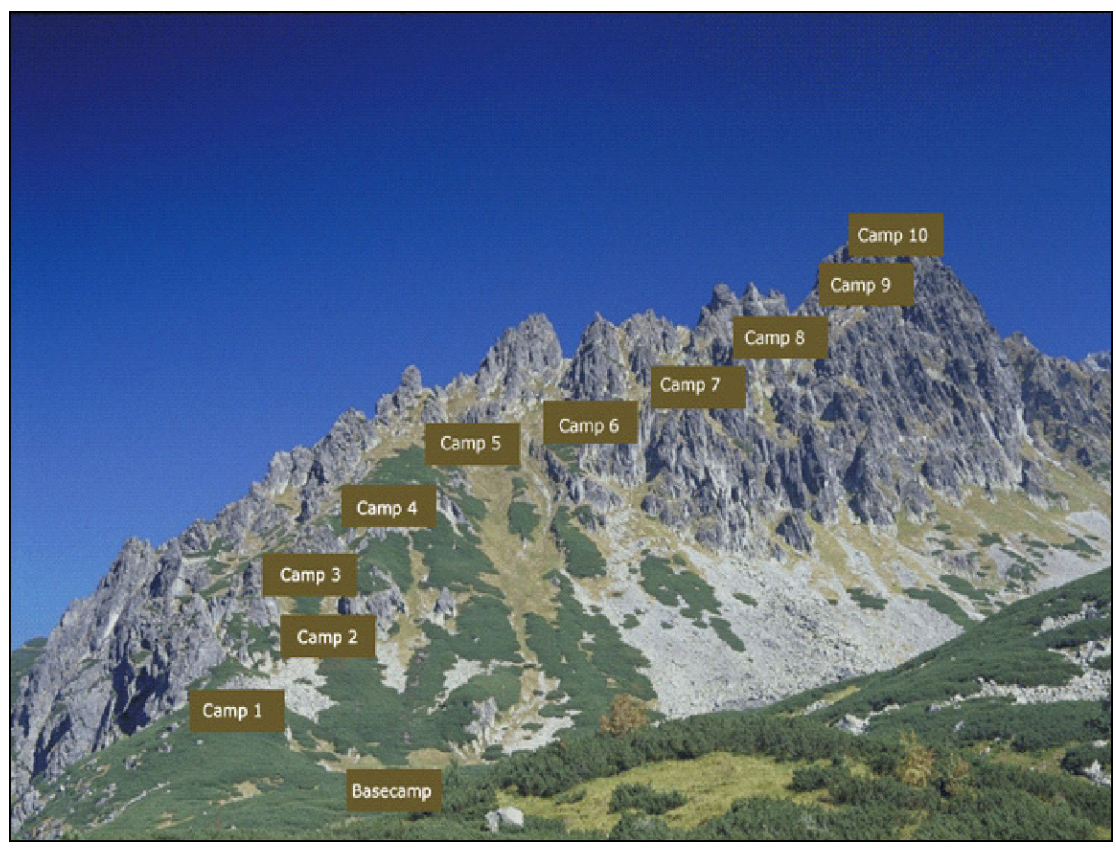

The pedagogical purpose of the Slovak e-learning course was to bridge the gaps between self-directed, open and task-based types of learning. Its aim was to increase the development of learners' overall communicative competence and enhance their autonomous learning. The focus was on the learners' activities; on what they could do with the language. While learners at the beginner's level are typically expected to create simple dialogues (e.g. introduce themselves, ask simple questions, and compose lists of items), learners at the intermediate level know how to employ their problem-solving skills and ability to search for required information to perform tasks such as telling as well as retelling a story and expressing their opinion. Learning activities consisted of both tasks with immediate feedback, which were focused primarily on language forms and accuracy, and collaborative practices (peer and group tasks) aimed at increasing communicative competence. The assessment was based on the completion of tasks and learners' active participation. 
Figure 2. Structure of a camp webpage ${ }^{3}$

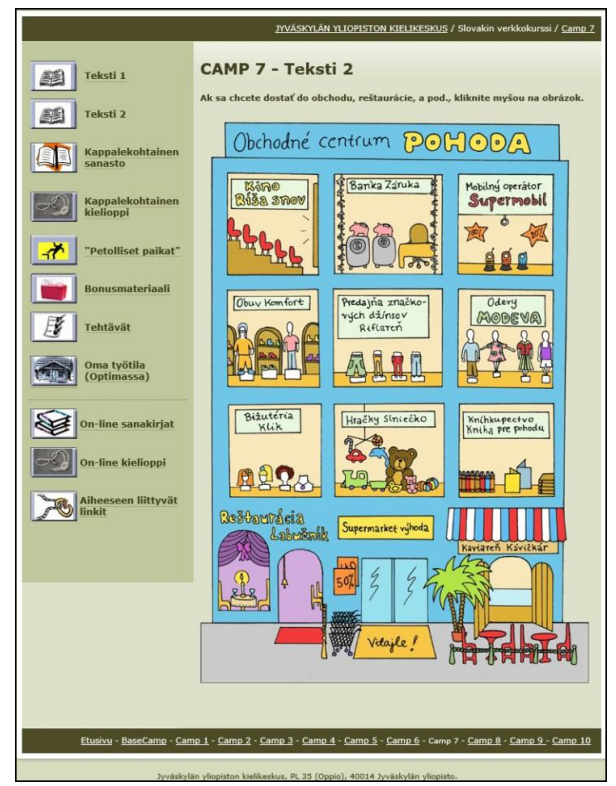

The website of the e-learning course was built around an image of the Slovak High Tatra Mountains, which acted likened the approach to learning Slovak to climbing a mountain. The climbing metaphor also depicted the challenges of teaching Slovak as one of the less commonly taught languages, pointing not only to the difficulty of climbing, but also the various external constraints that may endanger climbing (learning). In this metaphor, the teacher was both climbing guide and climber, one who was also constantly in danger but who also attempted to reach the summit together with the students. The course consisted of 10 camps. In accordance with the CEFR (2009), the curriculum was equivalent to the proficiency levels A1-B2. The starting point was Base Camp, which presented the basics of Slovak - its phonemic, morphological and lexicological system as well as information about its social use. Learning outcomes for respective camps were introduced on the startpage of the camp in the form of can do / know how to do statements. 
References to climbing and its symbols were part of the course layout. These included planning, getting familiar with the terrain (course), proceeding from the easiest towards the more difficult, and continuous skill improvement (e-learning skills and strategies). They complied with the idea of spiral learning: with each session learners expanded their skills and learned something new. While the content (i.e. the themes) of various camps varied, the website structure remained the same. Visual symbols corresponded with the metaphor of climbing (Kyppö 2014). For example, a rope symbolised language structures. A good rope was the guarantee of the best performance. Task sessions were illustrated by abseiling (i.e. a controlled descent), which corresponded with the lesson recaps. Dangerous places (i.e. tricky language issues) were denoted by warning signs. The mountain cabin was a safe place indicating each learner's own space in the Optima online environment.

\section{Data collection and analysis}

This section introduces the main areas of teacher investigation and provides some information on the collection and analysis of the data. The main questions (Table 1) address the students' experiences of learning Slovak in an e-learning environment, their views on the acquisition of all four language skills and the teacher's role in an e-learning environment. Nevertheless, the focus is on the learners' beliefs: what they believed they learned and/or did not learn, and how they experienced their learning.

Table 1. Research questions

\begin{tabular}{|l|l|}
\hline Focus & Question \\
\hline $\begin{array}{l}\text { Learning Slovak in an e-learning } \\
\text { environment. }\end{array}$ & $\begin{array}{l}\text { Do the learners of Slovak feel that they } \\
\text { learn the language in the e-learning } \\
\text { environment? }\end{array}$ \\
\hline $\begin{array}{l}\text { Learners' views on the acquisition } \\
\text { of language skills (speaking, listening, } \\
\text { reading and writing) in the e-learning } \\
\text { environment. }\end{array}$ & $\begin{array}{l}\text { Can all four language skills be equally } \\
\text { acquired in the e-learning environment? }\end{array}$ \\
\hline $\begin{array}{l}\text { Teacher's role (feedback, evaluation, } \\
\text { motivation) in the e-learning environment. }\end{array}$ & $\begin{array}{l}\text { What is the teacher's role as perceived } \\
\text { by the learners? }\end{array}$ \\
\hline
\end{tabular}


In 2008-2009, 22 students of Slovak at the University of Jyväskylä participated in the study. In 2010, 15 students from the University of Helsinki took part. The demographics of the groups were as follows: at the University of Jyväskylä, 21 students were female, 1 was male; 20 were Finnish and 1 was Polish. At the University of Helsinki, 8 students were male, 7 were female; 13 were Finnish, 1 was French and 1 was Japanese. They were all language students without any previous knowledge of Slovak. In addition to the contact sessions held once every two weeks in Jyväskylä, and once every three weeks in Helsinki, students were expected to learn independently. Their e-learning activities were monitored for the period of one academic term.

The data were collected from three questionnaires, personal interviews, learning journal content, course feedback and teacher reflections. A pre-course personal questionnaire was used to gather information about the personal and professional background of the students. The purpose was to obtain the maximum amount of information about their language learning history.

The data were analysed using thematic analysis (Braun \& Clark 2006). Taking a data-led approach, the collected data were initially described and then the items were divided into themes that were grouped as pre-, on- and post-course, and finally, the interpretations were developed.

\section{Key themes}

This chapter reports the key themes identified during the data analysis. The findings are presented under the pre-course, on-course and post-course themes and are accompanied by excerpts from the students' learning journals (Table 2).

The pre-course themes are related to the learners' concept of Slovakia and the Slovak language, their concept of learning with a special focus on e-learning, learners' expectations of the course, as well as their beliefs about themselves as e-learners. 
Table 2. Pre-course, on-course and post-course themes

\begin{tabular}{|l|l|l|l|}
\hline Pre-course themes & \multicolumn{2}{l|}{ On-course themes } & Post-course themes \\
\hline $\begin{array}{l}\text { Slovak language } \\
\text { and Slovakia }\end{array}$ & \multicolumn{2}{|l|}{ E-learning skills and strategies } & E-learning revisited \\
\hline $\begin{array}{l}\text { Students' beliefs of } \\
\text { themselves as learners }\end{array}$ & $\begin{array}{l}\text { Language } \\
\text { awareness }\end{array}$ & $\begin{array}{l}\text { Learning } \\
\text { awareness }\end{array}$ & Approaches to learning \\
\hline $\begin{array}{l}\text { Students' beliefs of } \\
\text { themselves as e-learners }\end{array}$ & $\begin{array}{l}\text { Linguistic } \\
\text { issues }\end{array}$ & $\begin{array}{l}\text { Manual vs. } \\
\text { digital writing }\end{array}$ & $\begin{array}{l}\text { Course evaluation } \\
\text { Self-evaluation }\end{array}$ \\
\hline $\begin{array}{l}\text { Learners' course } \\
\text { expectations }\end{array}$ & Motivation & $\begin{array}{l}\text { Approaches } \\
\text { to learning }\end{array}$ & $\begin{array}{l}\text { Teacher's role: teacher } \\
\text { \& student perspective }\end{array}$ \\
\hline
\end{tabular}

\subsection{Slovakia and Slovak language}

All learners had some knowledge of Slovakia and the Slovak language. For example, they knew that Slovak is a West Slavic language spoken in Slovakia. Slovak was perceived as a new language, which became a motivating factor. Two respondents chose Slovak because they knew it was considered to be a lingua franca of Slavic languages. They believed that the knowledge of Slovak might facilitate their study of other Slavic languages. Even though no specific reasons were given for learning Slovak, all respondents except for one strongly believed that they would be able to use Slovak in the future either for work or leisure purposes, especially when Slovakia joined the Eurozone in 2009.

\subsection{Learners' expectations of e-learning and their beliefs of themselves as learners}

Table 3 displays results of the thematic analysis aimed at learners' expectations of e-learning and their concept of themselves as learners.

Flexible learning is generally the secret of popularity for e-learning. Due to its novelty, the Slovak e-learning course was attractive for both the students and the teacher. All respondents expected the e-learning to be more flexible and more challenging than traditional classes, but some doubted whether they would be able to acquire all four languages skills. They were most sceptical about speaking. Nevertheless, they believed that the success of e-learning depends on their own 
efforts, so there was confidence that they might find a way of enhancing their spoken communication. Overall, learners' expectations of the course were high, and their belief in their own learning skills was strong. The use of a new learning environment was perceived as a valuable addition to traditional learning.

Table 3. Learners' expectations of e-learning and learners' concept of themselves as learners

\begin{tabular}{|l|l|l|l|}
\hline \multicolumn{2}{|l|}{$\begin{array}{l}\text { Learners' expectations } \\
\text { of e-learning }\end{array}$} & \multicolumn{2}{l|}{$\begin{array}{l}\text { Learners' concept } \\
\text { of themselves as learners }\end{array}$} \\
\hline PROS & CONS & PROS & CONS \\
\hline Efficiency & $\begin{array}{l}\text { Scepticism } \\
\text { about learning }\end{array}$ & $\begin{array}{l}\text { Independent } \\
\text { learning }\end{array}$ & Learning alone \\
\hline Novelty & Teacher's absence & $\begin{array}{l}\text { Learning through } \\
\text { positive experiences }\end{array}$ & $\begin{array}{l}\text { Superficial learning, } \\
\text { memorising }\end{array}$ \\
\hline Flexibility & Too much freedom & $\begin{array}{l}\text { Learning through } \\
\text { sudden insights }\end{array}$ & $\begin{array}{l}\text { Fear of unsuccessful } \\
\text { learning }\end{array}$ \\
\hline Challenge & Speaking \& writing & Task-based learning & Lack of printed text \\
\hline
\end{tabular}

The students saw themselves as independent learners that learn the most through positive experiences. Some of them believed in learning incidentally. The inherent interest of the content, motivation and the curiosity of learning a new language positively affected their learning. The terms "reasonable learning" - learning a foreign language with the prospect of using it in working life (instrumental motivation) - as well as "learning out of curiosity" occurred several times.

"I learn most efficiently when the subject is interesting. If the subject is too difficult, I need more time for learning...".

"If I know that I will be able to use my skills and knowledge in the future, then I get motivated".

Surprisingly, a few students expressed a preference for e-learning over faceto-face sessions. Two learners described themselves as superficial learners who generally learn through memorisation. Learning through a sudden insight occurred as well. 
"When learning, I mostly enjoy the moment when I get it, when I understand something that has not been taught directly...The moments when something clicks into place are the rewards for learning" (Student 3).

With the exception of two learners, all of the students perceived themselves as efficient learners if the content was interesting and if they knew that they would be able to apply their knowledge and skills in the future.

The on-course themes are related to the development of students' e-learning skills and strategies as well as the development of their language learning awareness. This development was reflected in the awareness of various issues related to the similarities and differences between languages, but also in how they became more conscious of their learning, in particular through writing.

\subsection{E-learning skills and strategies}

E-learning provides opportunities to employ a variety of learning styles. To ensure success in e-learning, two skills are necessary: the ability to adapt traditional study skills used in the face-to-face environment to online strategies, and the ability to adopt new strategies for learning and communicating in the online environment (Watkins 2007). Clarke (2008) argues that successful e-learning requires a solid foundation in traditional learning skills. In addition, learners are expected to acquire specific skills related to e-learning, such as time management and planning, responsibility for learning, self-assessment, problem solving, coping with stress, self-motivation, reflection, and research skills (e.g. planning, searching for information, assessing the quality of the obtained information). In line with Clarke's (2008) claims, in this course special emphasis was placed on the new e-learning skills. Students recognised self-assessment, self-reflection and collaboration as new and highly important skills for any learning. While only some students recognised their own learning styles and the impact of the e-learning environment on their learning strategies during the course, almost all of the respondents claimed that they benefitted from such new skills as selfassessment, self-reflection and collaboration. 


\subsection{Motivation}

Motivation in language learning is defined as learner's orientation to the goal of learning a second language (Norris-Holt 2001). While motivation theories generally focus on the amount of motivation compared to the results of learning, Guyan (2013) recommends that teachers focus instead on creating the conditions that facilitate the internalisation of learners' motivation in the online and classroom context. As part of Self-Determination Theory (SDT), Ryan and Deci (2008) propose the satisfaction of students' three basic needs: competence (a sense of being able to do something), autonomy (a sense of control and freedom) and relatedness (a sense of being connected to others).

The authors recommend the use of strategies which may be used in both online and classroom situations. Such strategies include, for example, allowing the learners some level of control, providing them with continuous and meaningful feedback, incorporating social elements into the course and giving them opportunities for collaboration. In the current study, learners were provided with continuous feedback and various opportunities for collaborative learning (e.g. simulations and task-based activities). Collaborative learning - sharing experiences and engaging in common tasks - was a new learning experience for most of the students.

Group motivation, perceived as part of group cohesion (Dörnyei 2001), was evident from the beginning of the course. It was reflected in various group activities, the purpose of which was to increase students' motivation by, for example, enriching their knowledge of Slovakia and its culture and meeting Slovak people. Despite the teacher's consistent efforts to maintain the group motivation, students' personal motivation was frequently at risk, especially when they were overwhelmed by stress due to a lack of time or proper planning.

To facilitate their learning and maintain their motivation, the teacher tried to preserve the balance between learning and personal life as well as to create more pleasant conditions for learning (Kyppö 2014). 


\subsection{Writing and language learning awareness}

Awareness plays an important role in the process of learning a new language and serves as an efficient motivator. The learners of Slovak successfully developed their learning awareness through listening and reading, but they failed to internalise the diacritic system of Slovak through digital writing. The problem with searching for the diacritical signs resulted in frustration and a loss of interest in writing. To solve this problem, students had the option to use the computer or to write by hand. Those who wrote by hand generally used the diacritic signs properly. In contrast, those who wrote with the computer either totally or partly ignored the diacritic system. This mix of approaches, making use of the technology and manual writing, often resulted in a compromise: scanning of the hand-written texts. Those who preferred manual writing claimed that writing by hand had a direct, positive impact on their awareness of learning Slovak.

"When I write in Slovak, it feels like painting. I enjoy it. I cannot get the same feeling on the computer" (Student 4).

These results reflect some of the latest research on manual writing, which suggests that writing by hand strengthens the learning process and that typing on a keyboard may mitigate it (see Saperstein Associates 2012). Studies have shown that when writing by hand, different parts of the brain are activated and the movements of the hand leave a motor memory in the sensorimotor aspect of bodily activity, which facilitates the recognition of the letters.

Other experiments suggest that there is a clear connection between touching, moving and acting, and human perception (Mangen \& Velay 2010 cited in Toft 2011). These results support the students' reported increase in language learning awareness for manual writing.

The post-course themes are related to learners' approaches to e-learning after the course, their approaches to learning and their evaluation of the course. They also include some reflections on the teacher's role (Table 4). 
Table 4. Learners' attitudes, perceptions and approaches to learning after the course

\begin{tabular}{|l|l|l|}
\hline $\begin{array}{l}\text { Attitudes } \\
\text { towards e-learning }\end{array}$ & $\begin{array}{l}\text { Learners' perceptions } \\
\text { of themselves as learners }\end{array}$ & $\begin{array}{l}\text { Approaches } \\
\text { to learning }\end{array}$ \\
\hline Lack of contact classes & New skills & Deep and strategic \\
\hline $\begin{array}{l}\text { E-learning for advanced } \\
\text { levels only }\end{array}$ & $\begin{array}{l}\text { New learning styles } \\
\text { and strategies }\end{array}$ & Language awareness \\
\hline Time constraints & $\begin{array}{l}\text { Identification with the } \\
\text { metaphor of climbing }\end{array}$ & Consciousness of learning \\
\hline Lack of planning & Increase in motivation & Cultural awareness \\
\hline $\begin{array}{l}\text { Challenge of writing: } \\
\text { awareness }\end{array}$ & $\begin{array}{l}\text { Language learning } \\
\text { awareness }\end{array}$ & Increase in motivation \\
\hline Motivation & Creativity & $\begin{array}{l}\text { Increase in communicative } \\
\text { competence }\end{array}$ \\
\hline Excessive flexibility & Successful learners & Increase in knowledge \\
\hline
\end{tabular}

\subsection{Attitudes towards e-learning revisited}

The Slovak e-learning course was generally considered to be appropriate for synchronous and asynchronous learning. Nevertheless, students believed that blended learning was the best option for learning not only Slovak but any less commonly taught language.

"Learning without the contact classes would have taken me ages! I have learned plenty of small (and big) things in the contact classes, things I wouldn't have noticed when learning completely alone..." (Student 6).

Students claimed that without the regular contact classes they would not have completed the course.

"Learning a completely new language in the e-learning environment is very difficult. I learn most on the contact lesson. When the teacher is physically present, my motivation to learn Slovak is far stronger" (Student 7).

E-learning was generally perceived to be highly motivating, but it was also seen as highly challenging due to the time constraints. Flexibility was regarded as the 
highest priority and, at the same, as the greatest obstacle in e-learning. Learning Slovak, as well as any other language at the beginner's level, was considered to be too demanding in this particular learning environment. Nonetheless, the presence of the new skills and specific strategies for e-learning (e.g. selfestimation, self-reflection and collaboration) was recognised.

\subsection{Learners' agency: approaches to learning}

In line with Entwistle's (2001) model of approaches to learning, all learners made a constant effort to understand Slovak and learn a significant amount. Except for one, all respondents regarded themselves as independent learners with the deep approach to learning. Their participation in the course was based on their personal interest and group commitment, which resulted in deep learning and minimum dropout.

Basharina (2009) suggests that e-learning consists of a complex interrelationship between the affordances and constraints of a learning environment and a learner's agency. Although students with the deep approach to learning generally employ more effective learning strategies, actively seek meaning and benefit the most from learning, the students with the strategic approach to learning put consistent effort into learning, provide themselves with the right conditions for study and good learning materials, and monitor the effectiveness of their learning strategies (Thorpe 2002). In the context of this study, the strategic approach to learning reflects the consistency of effort needed for studying that is expressed in the course's climbing metaphor. During the course, students were constantly building on their previous experience of language learning, comparing the target language to previously acquired languages (see Mayes \& de Freitas 2013).

"I had a great time on the course! This is for me more like a hobby than any 'obligatory' study... When I am learning, I can feel how all that is getting saved deeply somewhere in my mind. That is learning. In the contact class, it is the teacher who generally provides the answers to the questions but on the e-learning course it is the learner who attempts to get the answers..." (Student 8). 
Along with the development of their learning awareness, students also became sensitive to Slovak culture, thereby building what Dufva (2004) calls cultural awareness. Learners' reflections revealed an evident increase in learning awareness and a solid belief that they had achieved significant learning gains.

\subsection{Teacher's role}

The teaching experiment revealed some of the teacher's multiple roles: linguistic and cultural informant, expert and negotiator (Dufva 1994a), facilitator, mentor, student, and participant in the continuous dialogue. The metaphor of teacher as a mountain guide provided a guarantee that the climbers (students) would reach the top (learning objectives). Thus the teacher was seen as a tutor, guide, facilitator and, above all, as a friend.

The students' reflections revealed that their motivation to learn was higher when the teacher was present. This aligns with Kock's (2005) claim that the teacher in the contact class represents a natural medium that may contribute to learners' psychological engagement and promote an increase in motivation. Interestingly, even the teacher's virtual presence may have a significant impact on the learners through the design of the learning environment and through the enhancement of learner interaction (Phillips 2014; Stewart 2014).

\subsection{Assessment of the e-learning course}

The e-learning course was continuously evaluated and developed by both the learners and the teacher. The course was evaluated from the viewpoint of clarity, authenticity, functionality and relevance. In the students' opinion, a learning environment should not only be practical and easy to navigate, but also pleasant and motivating, especially when the target language is a less commonly taught language and the learning community is small in size. Blended learning was regarded as the best option for learning Slovak, a result that agrees with the results of other studies examining student satisfaction with blended, online and face-to-face courses (Diaz \& Entonado 2009; Lim \& Morris 2009; Solimeno, Mebane, Tomai \& Francescato 2008). The overall organisation of the course, 
including the teacher's individual and group feedback, was considered to be an inevitable prerequisite not only for successful completion of the course, but also for further Slovak studies.

The metaphor of learning as climbing and the overall layout of the course had a positive impact on students' activities. The course structure and layout was perceived as well organised, functional and visually attractive. Table 5 presents a summary of the students' feedback, including an overall evaluation of the course, the e-learning environment and the course structure.

Table 5. Course evaluation: student perspective

\begin{tabular}{|l|l|l|}
\hline $\begin{array}{l}\text { Course evaluation (overall) } \\
\text { criteria }\end{array}$ & $\begin{array}{l}\text { e-Learning environment } \\
\text { criteria }\end{array}$ & $\begin{array}{l}\text { Course structure } \\
\text { (camps, sections) }\end{array}$ \\
\hline Clarity & Authenticity & Relevant \\
Authenticity & Flexibility & Clear \\
Functionality & Immediate feedback & Appropriate \\
Relevancy & Time for reflection & Up-to-date \\
Learner-centeredness & Collaboration & Interesting \\
Promoting learner agency & Supportive atmosphere & Pleasant \\
Novelty & Consistent interaction & Challenging \\
Promoting collaboration & Promoting learner autonomy & Motivating \\
\hline
\end{tabular}

In addition to the development of students' communicative competence in Slovak, one of the purposes was to inspire learners and arouse their interest in Slovak studies. Based on the students' feedback and reflections, this objective was met.

\section{Concluding remarks and implications}

The initial research questions of this study were whether and how Slovak is learned in an e-learning environment and to what extent a good command of all four language skills, especially writing and speaking, may be acquired. The findings showed that an e-learning environment may be used for learning less commonly taught languages. However, not all language skills may be acquired at an equal level without contact classes. Furthermore, the results show that 
this particular learning environment promotes the feeling in students that they have learned Slovak (identifying with the metaphor of learning as if climbing). All of the learners, with the exception of two, believed that they learned a good deal about Slovak. Based on their reflections, the learners showed clear progress in their receptive skills (reading and listening), but had difficulty in developing their productive skills (speaking and writing). The problem of digital writing was resolved with a compromise in which the learners were given the freedom to choose the writing medium. Blended learning - faceto-face classroom tutorials and computer-mediated activities - was used to compensate for the lack of spontaneous speaking. Furthermore, new e-learning skills such as research, content creation and collaboration were adopted and further developed.

This teaching experiment shows that technology-enhanced learning of lesser commonly taught languages can be successful. Nevertheless, from the viewpoint of sustainable learning (i.e. knowledge management and exchange in the target language), the contact classes may be more efficient, particularly at the beginners' level. The greatest challenge in teaching and learning less commonly taught languages in an e-learning environment is the availability of web-learning resources and the development of new pedagogies. While numerous readymade web-learning materials and sophisticated learning spaces for major languages are constantly offered, very few effective web materials may be found for less commonly taught languages. The teacher thus often ends up being the course designer and developer. However, current developments and innovations in language learning and teaching emphasise the use of learnercentred pedagogies in new, personalised learning environments. Rapidly growing mobile technologies and the use of social media offer new learning platforms for the development of all areas of communicative competence. The emergence of social networking tools removes the borders of the traditional concept of a learning environment and opens the gate towards multiple learning spaces, both physical and virtual. New technological opportunities that involve the integration of new media modes such as blogs and wikis into learning activities make use not only of multiple resources and learning environments, but also of the interconnectivity and social participation among 
the learners (Mcloughlin \& Lee 2008). This type of interaction may result in an increase of the learners' communicative competence and motivation.

\section{References}

Bakhtin, M. M. 1981. The dialogic imagination. Four essays. Austin: University of Texas Press.

Basharina, O. 2009. Student agency and language learning pocesses and outcomes in international online environments. CALICO Journal, 26 (2), 390-412.

Biggs, J. 2003. Teaching for quality learning at university - What the student does (2nd ed.). Buckingham: Open University Press.

Bilash, O. \& Tulasiewicz, W. 1995. Language awareness - Its place in the Canadian context. In K. A. McLeod (ed.), Multicultural education: the state of the art. Toronto: CASLT.

Braun, V. \& Clark, V. 2006. Using thematic analysis in psychology. Qualitative Research in Psychology, 3 (2), 77-101. doi:10.1191/1478088706qp063oa

Brecht, R. D. \& Walton, A. R. 1994. National strategic planning in the less commonly taught languages. Washington DC: National Foreign Language Center.

Brown, D. 2014. Agency and motivation to achieve language-learning objectives among learners in an academic environment in France. APPLES - Journal of Applied Language Studies, 8 (1), 101-126.

Byram, M., Nichols, A. \& Stevens, D. 2001. Developing intercultural competence in practice. Clevedon: Multilingual Matters.

CEFR 2001. Common European Framework of Reference for Languages: Learning, teaching, assessment. Cambridge University Press.

CEFR 2009. Common European framework of reference for languages : learning, teaching, assessment. A Guide for users. Strasbourg: Language Policy Division.

Clarke, A. 2008. eLearning skills. New York: Palgrave Macmillan.

Diaz, L. A. \& Entonado, F. B. 2009. Are the functions of teachers in e-learning and face-to-face learning environments really different? Educational Technology \& Society, 12 (4), 331-343.

Dörnyei, Z. 1991. Motivation in second and foreign language learning. Language Teaching, 31 (3), 117-135. doi:10.1017/S026144480001315X

Dörnyei, Z. 1998. Motivation in second and foreign language learning. Language Teaching, 31 (3),117-135. doi:10.1017/S026144480001315X 
Dörnyei, Z. 2001. Teaching and researching motivation. Harlow: Longman.

Dufva, H. 1994a. Language awareness and cultural awareness for language learners. Hungarologische Beiträge 2, Probleme des Spracherwerbs. Jyväskylä: Hungarologia.

Dufva, H. 1994b. Everyday knowledge of language: a dialogical approach to awareness. Finlance, A Finnish Journal of Applied Linguistics, 13 (2), 22-49.

Dufva, H. 2004. Language, thinking and embodiment: Bakhtin, Whorf and Merleau-Ponty. In F. Bostad, C. Brandist, L. S. Evensen \& H. C. Faber (eds.), Bakhtinian perspectives on language and culture: meaning in language, art and new media. Houndmills, Basingstoke, Hampshire: Palgrave Macmillan, 133-146.

Ellis, R. 2003. Task-based learning and teaching. Oxford: Oxford University Press.

Engeström, Y. 1999. Activity theory and individual and social transformation. In Y. Engeström, R. Miettinen \& R.-L. Punamäki (eds.), Perspectives on activity theory. Cambridge: Cambridge University Press.

Entwistle, N. J. 2001. Styles of learning and approaches to studying in higher education. Kybernetes, 30 (5/6), 593-602. doi:10.1108/03684920110391823

Guyan, M. 2013. Improving motivation in e-learning. e-Learn Magazine, October 2013. Retrieved from http://elearnmag.acm.org/featured.cfm?aid=2527388

Johnson, M. 2004. A philosophy of second language acquisition. New York: Yale University Press.

Kock, N. 2005. Media richness or media naturalness? The evolution of our biological communication apparatus and its influence on our behavior toward E-communication tools. IEEE Transactions on Professional Communication, 48 (2), 117-30. doi:10.1109/ TPC.2005.849649

Kyppö, A. 2007. A long way to the top of a mountain. In M. Kalin, A. Räsänen \& T. Nurmi (eds.), Kirjomme kielillä, Jyväskykön yliopiston kielikeskus 30 vuotta. Tapestry of Teaching. University of Jyväskylä Language Centre 30.Year. Jyväskylä: Univeristy of Jyväskylä, 132-140.

Kyppö, A. 2014. Learning Slovak in an e-learning environment: a case study. APPLES Journal of Applied Language Studies, 8 (1), 127-146.

Lim, D. H. \& Morris, M. L. 2009. Learner and instructional factors influencing learning outcomes within a blended learning environment. Educational Technology \& Society, 12 (4), 282-293.

Mangen, A. \& Velay, J.-L. 2010. Digitizing literacy: reflections on the haptics of writing. In M. H. Zadeh (ed.) Advances in Haptics. Intech. doi:10.5772/8710 
Mayes, T. \& de Freitas, S. 2013. Review of e-learning theories, frameworks and models. Joint Information Systems Committee. London. Retrieved from http://www.jisc.ac.uk/ whatwedo/programmes/elearningpedagogy/outcomes.aspx

McLoughlin, C. \& Lee, M. J.W. 2008. The three P's of pedagogy for the networked society: personalization, participation, and productivity. International Journal of Teaching and Learning in Higher Education, 20 (1), 10-27.

Norris-Holt, J. 2001. Motivation as a contributing factor in second language acquisition. The Internet TESL Journal. Retrieved from http://iteslj.org/Articles/Norris-Motivation.html

Ondrejovič, S. 2009. The Slovak language. Languages in Slovakia. Ministry of Foreign Affairs of the Slovak Republic. Bratislava: Public Diplomacy Department.

Phillips, B. 2014. How technology has affected the learning environment. brennaphillips. com. Retrieved from http://www.brennaphillips.com/how-technology-has-affected-thelearning-environment

Robert, L. P. \& Dennis, A. R. 2005. Paradox of richness: a cognitive model of media choice. IEEE Transactions on Professional Communication, 48 (1), 10-21. doi:10.1109/ TPC.2004.843292

Ryan, E. L. \& Deci, R. M. 2008. Facilitating optimal motivation and psychological well-being across life's domains. Canadian Psychology, 49 (1), 14-23. doi:10.1037/0708-5591.49.1.14

Saperstein Associates, 2012. Handwriting in the 21st century? An educational summit. Retrieved from https://www.hw21summit.com/media/zb/hw21/files/H2948_HW_ Summit_White_Paper_eVersion.pdf

Solimeno, A., Mebane, M. E., Tomai, M. \& Francescato, D. 2008. The influence of students and teachers characteristics on the efficacy of face-to-face and computer supported collaborative learning. Computers \& Education, 51 (1), 109-128.

Stewart, M. 2014. Designing for emergence: the role of the instructor in student-centered learning. Hybrid Pedagogy Journal. Retrieved from http://www.hybridpedagogy.com/ journal/designing-emergence-role-instructor-student-centered-learning/

Thorpe, M. 2002. From independent learning to collaborative learning: New communities of practice in open, distance and distributed learning. In M. Lea \& K. Nicoll (Eds.), Distributed learning: Social and cultural approaches to practice. London: Routledge.

Toft, T. E. 2011. Better learning through handwriting. ScienceDaily. Retrieved from www. sciencedaily.com/releases/2011/01/110119095458.htm

Ushida, E. 2005. The role of students' attitudes and motivation in second language learning in online language courses. CALICO Journal, 23 (1), 49-78. 
Van Lier, L. 2010. The ecology of language learning: practice to theory, theory to practice. Procedia - Social and Behavioral Sciences, 3 (2-6), 1276-1284. doi:10.1016/j. sbspro.2010.07.005

Vaughan, N. D. 2010. Blended learning. In M.F. Cleveland-Innes \& D.R. Garrison, An introduction to distance education: understanding teaching and learning in a new era. New York: Routledge

Vygotsky, L. S. 1986. Thought and language. Cambridge: MIT.

Watkins, R. 2007. E-learning study skills and strategies. Distance Learning, 1 (3), 24-26.

Willis, J. 1996. A framework for task-based learning. London: Longman.

Wilson, B. G. 1996. Constructivist learning environments: case studies in instructional design. New Jersey: Educational Technology Publications. 


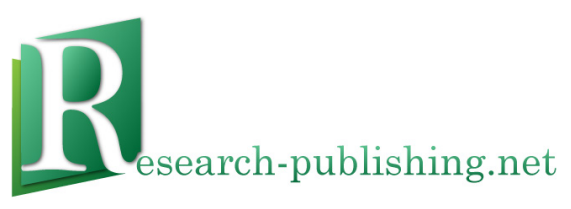

Published by Research-publishing.net, not-for-profit association Dublin, Ireland; Voillans, France, info@research-publishing.net

(C) 2015 by Research-publishing.net (collective work)

Each author retains their own copyright

Voices of pedagogical development - Expanding, enhancing and exploring higher education language learning Edited by Juha Jalkanen, Elina Jokinen, \& Peppi Taalas

Rights: All articles in this collection are published under the Attribution-NonCommercial -NoDerivatives 4.0 International (CC BY-NC-ND 4.0) licence. Under this licence, the contents are freely available online (as PDF files) for anybody to read, download, copy, and redistribute provided that the author(s), editorial team, and publisher are properly cited. Commercial use and derivative works are, however, not permitted.

\section{()ㅛ $\Theta \Theta$}

Disclaimer: Research-publishing.net does not take any responsibility for the content of the pages written by the authors of this book. The authors have recognised that the work described was not published before, or that it is not under consideration for publication elsewhere. While the information in this book are believed to be true and accurate on the date of its going to press, neither the editorial team, nor the publisher can accept any legal responsibility for any errors or omissions that may be made. The publisher makes no warranty, expressed or implied, with respect to the material contained herein. While Research-publishing.net is committed to publishing works of integrity, the words are the authors' alone.

Trademark notice: Product or corporate names may be trademarks or registered trademarks, and are used only for identification and explanation without intent to infringe.

Copyrighted material: Every effort has been made by the editorial team to trace copyright holders and to obtain their permission for the use of copyrighted material in this book. In the event of errors or omissions, please notify the publisher of any corrections that will need to be incorporated in future editions of this book.

Typeset by Research-publishing.net

Cover design by (C) Antti Myöhänen

ISBN13: 978-1-908416-25-4 (Paperback - Print on demand, black and white)

Print on demand technology is a high-quality, innovative and ecological printing method, with which the book is never 'out of stock' or 'out of print'.

ISBN13: 978-1-908416-26-1 (Ebook, PDF, colour)

ISBN13: 978-1-908416-27-8 (Ebook, EPUB, colour)

Legal deposit, Ireland: The National Library of Ireland, The Library of Trinity College, The Library of the University of Limerick, The Library of Dublin City University, The Library of NUI Cork, The Library of NUI Maynooth, The Library of University College Dublin, The Library of NUI Galway.

Legal deposit, United Kingdom: The British Library.

British Library Cataloguing-in-Publication Data.

A cataloguing record for this book is available from the British Library.

Legal deposit, France: Bibliothèque Nationale de France - Dépôt légal: septembre 2015. 